\title{
Soil Potassium Fractions as Influenced by Integrated Fertilizer Application Based on Soil Test Crop Response under Maize-Wheat Cropping Systems in Acid Alfisol
}

\author{
Ibajanai Kurbah* and S. P. Dixit
}

Dept. of Soil Science, CSK Himachal Pradesh Agricultural University, Palampur, District Kangra, H.P. (176 062), India

\section{Corresponding Author}

Ibajanai Kurbah

e-mail: ibakurbah@gmail.com

\author{
Article History \\ Article ID: IJEP0291 \\ Received in $18^{\text {th }}$ February, 2019 \\ Received in revised form $25^{\text {th }}$ February, 2019 \\ Accepted in final form $27^{\text {th }}$ February, 2019
}

\begin{abstract}
Field experiments were conducted during 2014-15 to 2015-16 at the Experimental Farm of Department of Soil Science, CSK Himachal Pradesh Krishi Vishvavidyalaya, Palampur, HP as a part of long-term fertilizer experiment initiated in kharif, 2007 in a maize-wheat sequence. The experiment consisted of eight treatments viz., (1) control; (2) general recommended dose; (3) soil test based; (4) farmers' practice; (5) target yield of 25 and 30 for rabi and kharif, respectively without FYM; (6) target yield of 25 and 30 for rabi and kharif, respectively with FYM @ $5 \mathrm{t} \mathrm{ha}^{-1}$ (7) target yield of 35 and $40 \mathrm{q} \mathrm{ha}^{-1}$ for rabi and kharif, respectively without FYM; (8) target yield of 35 and $40 \mathrm{q} \mathrm{ha}{ }^{-1}$ for rabi and kharif, respectively with FYM @ $5 \mathrm{t} \mathrm{ha}^{-1}$ ) which were replicated thrice in a randomized block design. The fertilizer adjustment equations were developed based on target yield concept and accordingly nutrient doses were calculated. The results revealed that soil available $\mathrm{K}$ was significantly increased in both the target yields with IPNS over general recommended dose and soil test based treatments. The different forms of potassium i.e. water soluble K, exchangeable K and non- exchangeable K were highest under STCR (IPNS) treatment for target yield of $35 \mathrm{q} \mathrm{ha}^{-1}$. The status of non-exchangeable potassium was significantly inferior in unfertilized plots in comparisons to all other treatments. Regression analysis showed that exchangeable $\mathrm{K}$ was the most important variable contributing about $94 \%$ in the total variation in available- $\mathrm{K}$.
\end{abstract}

Keywords: Cropping sequence, IPNS, maize, potassium, STCR, wheat

\section{Introduction}

Efficient nutrient management is one of the key management strategies in current agriculture to achieve required food production to feed rapidly growing population. Potassium has long been a neglected nutrient in Indian agriculture (Sanyal, 2014). Potassium requirement of crops are in general identical to nitrogen. Over extraction of $\mathrm{K}$ from soil due to continuous mismatch between crop demand and external supply results in depletion of $\mathrm{K}$ reserve. Balanced application of fertilizers is needed for sustainable crop production and maintenance of soil health. Long term fertilizer experiments have shown a comparatively better yield of crops when balanced NPK fertilizers are used in comparisons to NP use only (Dutta et al., 2015).

Potassium exists in soil in different forms viz., water soluble, exchangeable $\mathrm{K}$, non exchangeable $\mathrm{K}$ (fixed $\mathrm{K}$ ) and mineral $\mathrm{K}$. In India, the current $\mathrm{K}$ fertilizer recommendations based on assessment by neutral normal $\mathrm{NH}_{4} \mathrm{OAc}$ extractable $\mathrm{K}(\mathrm{pH} 7)$ is commonly followed (Rao, 2014). Equilibrium exists among different forms that affect level of $\mathrm{K}$ in soil solution at particular time and availability of $\mathrm{K}$ in plants. The distribution of these forms in soils is important in understanding the conditions controlling their availability to growing crops. Knowledge and understanding of $\mathrm{K}$ dynamics in soil proves to be the best approach in arriving at fertilizer recommendation for crops. Soil characteristics, management practices, plant type and environmental conditions greatly influenced availability of each form of $\mathrm{K}$ in soil. Knowledge and understanding of $\mathrm{K}$ dynamic in soil proves to be the best approach in arriving at fertilizer recommendation for crops.

Application of fertilizers based on soil test nutrient availability and crop response to fertilizer applied for specific yield target is considered as a soil and fertilizer based precision farming strategy to achieve target food grain production as well as reducing environmental degradation. The present study was, therefore, under taken to assess the effect of soil test crop response based fertilizer recommendations on soil potassium dynamics under maize-wheat cropping system.

\section{Materials and Methods}

\subsection{Field experiments}

The present study was undertaken as a part of long-term fertilizer experiment initiated in kharif, 2007 in a maizewheat sequence at the Experimental Farm of Department of 
Soil Science, CSK Himachal Pradesh Krishi Vishvavidyalaya, Palampur, HP. The experimental farm is situated at $32^{\circ} 6^{\prime}$ $\mathrm{N}$ latitude and $76^{\circ} 3^{\prime} \mathrm{E}$ longitude at an elevation of 1290 $\mathrm{m}$ above mean sea level. The climate of the experimental site is characterized as wet-temperate, with mild summers and cool winters. Taxonomically, the soil of the study area falls in the order Alfisol and sub group Typic Hapludalf (Verma, 1979). The soil of the experimental site at initiation of experiment was acidic in reaction and silty clay loam in texture. The experiment was laid out in randomized block design (RBD) with eight treatments (Table 1).

\begin{tabular}{|c|c|c|}
\hline $\begin{array}{l}\text { Treat- } \\
\text { ment }\end{array}$ & Kharif maize & Rabi wheat \\
\hline $\mathrm{T}_{1}$ & Control & Control \\
\hline $\mathrm{T}_{2}$ & $\begin{array}{l}\text { Farmers' practice i.e. } 25 \% \\
\text { of general recommended } \\
\text { dose } \mathrm{N}+5 \mathrm{t} \mathrm{ha}^{-1} \mathrm{FYM} \text { on } \\
\text { dry weight basis }\end{array}$ & $\begin{array}{l}\text { Farmers' practice i.e. } \\
25 \% \text { of general recom- } \\
\text { mended dose } N+5 \\
\text { ha }^{-1} \text { FYM on dry weight } \\
\text { basis }\end{array}$ \\
\hline $\mathrm{T}_{3}$ & $\begin{array}{l}\text { General Recommended } \\
\text { Dose (GRD) i.e. } 120,60 \text {, } \\
40 \mathrm{~kg} \mathrm{ha}^{-1} \mathrm{~N}, \mathrm{P}_{2} \mathrm{O}_{5} \text { and } \\
\mathrm{K}_{2} \mathrm{O} \text {, respectively) }\end{array}$ & $\begin{array}{l}\text { General Recommended } \\
\text { Dose (GRD) i.e. } 120,60 \text {, } \\
30 \mathrm{~kg} \mathrm{ha}^{-1} \mathrm{~N}, \mathrm{P}_{2} \mathrm{O}_{5} \text { and } \\
\mathrm{K}_{2} \mathrm{O} \text {, respectively) }\end{array}$ \\
\hline $\mathrm{T}_{4}$ & $\begin{array}{l}\text { Soil test based fertilizer } \\
\text { application }\end{array}$ & $\begin{array}{l}\text { Soil test based fertilizer } \\
\text { application }\end{array}$ \\
\hline $\mathrm{T}_{5}$ & $\begin{array}{l}\text { NPK dose for target } 30 \\
\mathrm{q} \mathrm{ha}^{-1}\end{array}$ & $\begin{array}{l}\text { NPK dose for target } 25 \\
\text { q ha }^{-1}\end{array}$ \\
\hline $\mathrm{T}_{6}$ & $\begin{array}{l}\text { NPK dose for target } 30 \text { q } \\
\text { ha-1 with FYM @ } 5 \text { t ha-1 }\end{array}$ & $\begin{array}{l}\text { NPK dose for target } 25 \mathrm{q} \\
\text { ha-1 with FYM @ } 5 \text { t ha }^{-1}\end{array}$ \\
\hline $\mathrm{T}_{7}$ & $\begin{array}{l}\text { NPK dose for target } 40 \\
\mathrm{q} \mathrm{ha}^{-1}\end{array}$ & $\begin{array}{l}\text { NPK dose for target } 35 \\
\text { q ha }^{-1}\end{array}$ \\
\hline $\mathrm{T}_{8}$ & $\begin{array}{l}\text { NPK dose for target } 40 \text { q } \\
\text { ha-1 with FYM @ } 5 \text { t ha-1 }\end{array}$ & $\begin{array}{l}\text { NPK dose for target } 35 \text { q } \\
\text { ha }^{-1} \text { with FYM @ } 5 \text { t ha-1 }\end{array}$ \\
\hline
\end{tabular}

Nutrients doses $\left(\mathrm{kg} \mathrm{ha}^{-1}\right)$ were calculated from the fertilizer adjustment equations for targeting yield of maize and wheat crop:

\begin{tabular}{ll}
\hline Maize & Wheat \\
\hline $\mathrm{FN}=5.88 \mathrm{~T}-0.23 \mathrm{SN}-0.93 \mathrm{ON}$ & $\mathrm{FN}=5.27 \mathrm{~T}-0.25 \mathrm{SN}-1.06 \mathrm{ON}$ \\
$\mathrm{FP}_{2} \mathrm{O}_{5}=4.87 \mathrm{~T}-1.22 \mathrm{SP}-0.81 \mathrm{OP}$ & $\mathrm{FP}_{2} \mathrm{O}_{5}=4.13 \mathrm{~T}-0.38 \mathrm{SP}-0.98$ \\
& $\mathrm{OP}$ \\
$\mathrm{FK}_{2} \mathrm{O}=3.66 \mathrm{~T}-0.49 \mathrm{SK}-0.51 \mathrm{OK}$ & $\mathrm{FK}_{2} \mathrm{O}=2.87 \mathrm{~T}-0.15 \mathrm{SK}-0.55$ \\
& $\mathrm{OK}$ \\
\hline
\end{tabular}

In above equations, $\mathrm{FN}, \mathrm{FP}_{2} \mathrm{O}_{5}, \mathrm{FK}_{2} \mathrm{O}$ are doses of $\mathrm{N}, \mathrm{P}_{2} \mathrm{O}_{5}$ and $\mathrm{K}_{2} \mathrm{O}$, respectively in $\mathrm{kg} \mathrm{ha}^{-1}$. $\mathrm{T}$ is yield target ( $\mathrm{q} \mathrm{ha} \mathrm{h}^{-1}$ ), SN, SP and $\mathrm{SK}$ are soil available $\mathrm{N}, \mathrm{P}$ and $\mathrm{K}$, respectively in $\mathrm{kg} \mathrm{ha}^{-1}$. $\mathrm{ON}, \mathrm{OP}$ and $\mathrm{OK}$ are N, P and $\mathrm{K}$ that were supplied through
FYM kg ha-1, respectively.

\subsection{Soil sampling}

Plot-wise composite soil samples (0-0.15 m depth) were collected from each plot after harvest of wheat crop (2014-15 and 2015-16). The soil samples were dried in shade, ground in pestle mortar, passed through $2 \mathrm{~mm}$ sieve and subjected to laboratory analysis

\subsection{Analysis of soil samples}

Soil samples were analyzed for available $\mathrm{K}$ using $1 \mathrm{~N}$ Ammonium Acetate ( $\mathrm{pH} 7$ ) given by Black (1965). Different fractions of potassium viz., water soluble, exchangeable and non exchangeable potassium were determined as per the procedure listed below:

a) Water-soluble K: Water-soluble $\mathrm{K}$ was extracted by shaking the soil water suspension in the ratio of 1:5 for one hour then filtered, and K was determined (Grewal and Kanwar, 1966).

b) Exchangeable $\mathrm{K}: 50 \mathrm{ml}$ of $1 \mathrm{~N}$ Ammonium acetate was added to ten grams of soil taken in a $125 \mathrm{ml}$ flask, thoroughly mixed and kept overnight. Then the soil was filtered, washed with neutral $1 \mathrm{~N} \mathrm{NH}_{4} \mathrm{OAc}$ until volume of $100 \mathrm{ml}$ was obtained and $\mathrm{K}$ was determined. The amount of exchangeable $\mathrm{K}$ was calculated by subtracting water soluble $\mathrm{K}$ from $\mathrm{K}$ extracted with neutral 1 $\mathrm{N} \mathrm{NH}_{4} \mathrm{OAc}$ (Merwin and Peeech, 1950).

c) Non exchangeable $\mathrm{K}$ : Twenty five $\mathrm{ml}$ of $1 \mathrm{~N} \mathrm{HNO}_{3}$ was added to $2.5 \mathrm{~g}$ of soil taken in $100 \mathrm{ml}$ beaker, kept for 15 minutes, the beaker was covered with watch glass and then boiled for 10 minutes. The soil was then filtered into a $50 \mathrm{ml}$ of volumetric flask washed with $0.1 \mathrm{~N} \mathrm{HNO}_{3}$ until the filtrate was brought to volume and quantity of $\mathrm{K}$ was determined. The non exchangeable $\mathrm{K}$ was calculated by subtracting $\mathrm{K}$ extracted with neutral normal $\mathrm{NH}_{4} \mathrm{OAc}$ from $\mathrm{K}$ extracted in hot $1 \mathrm{~N} \mathrm{HNO}_{3}$ (Sutton and Seay, 1958).

\subsection{Statistical analysis}

The data generated from the field and laboratory studies were subjected to statistical analysis using the technique of analysis of variance for randomized block design for the interpretation of results as described by Gomez and Gomez (1984).

\section{Results and Discussion}

\subsection{Available $K$}

After wheat harvest (rabi, 2014-15), the available $\mathrm{K}$ significantly increased by $21.4 \%$ in farmers' practice over control (Table 2). The treatment target yield of 25 and $35 \mathrm{q}$ ha $^{-1}$ with FYM significantly improved the available $\mathrm{K}$ content by 1.5 and 3.3 per cent over the same treatment without FYM. During second year i.e. after harvest of wheat (rabi, 2015-16), the lowest values of available $K$ in $T_{1}$ was significantly inferior over all other treatments. Farmers' practice and general recommended dose treatments increased available K content in soil by 31.3 and $32.8 \%$ over control. The treatment target yield of 25 and $35 \mathrm{q} \mathrm{ha}^{-1}$ without FYM increased the available 
Table 2: Effect of prescription based fertilizer application on available $\mathrm{K}$ status of soil $\left(\mathrm{kg} \mathrm{ha}^{-1}\right)$

\begin{tabular}{lcc}
\hline Treatment & \multicolumn{2}{c}{$\mathrm{K}$} \\
\cline { 2 - 3 } & $2014-15$ & $2015-16$ \\
\hline $\mathrm{T}_{1}:$ Control & 210 & 198 \\
$\mathrm{~T}_{2}:$ Famers' Practice & 255 & 260 \\
$\mathrm{~T}_{3}$ : General Recommended dose & 265 & 263 \\
$\mathrm{~T}_{4}$ : Soil Test Based & 268 & 265 \\
$\mathrm{~T}_{5}:$ Target yield 25 q ha-1 & 270 & 271 \\
$\mathrm{~T}_{6}:$ Target yield 25 q ha ${ }^{-1}$ with FYM @ & 272 & 275 \\
5 t ha-1 & & \\
$\mathrm{T}_{7}:$ Target yield 35 q ha-1 & 276 & 273 \\
$\mathrm{~T}_{8}:$ Target yield $35 \mathrm{q} \mathrm{ha}^{-1}$ with FYM @ & 284 & 282 \\
5 t ha-1 & & \\
$\mathrm{CD} p=0.05$ & 12.0 & 12.1 \\
\hline
\end{tabular}

$\mathrm{K}$ content by 3.0 and $3.8 \%$ over general recommended dose.

The available $\mathrm{K}$ content in control was lowest due to continuous cropping and no addition of $\mathrm{K}$ from external sources. This reduction of soil available $\mathrm{K}$ in comparison to the initial value might be due to continuous mining of the soil native pool that also caused reduction in crop yield (Katkar et al., 2011). Tiwari et al. (2013); Ram et al. (2016) reported that available $\mathrm{K}$ content improved when farmyard manure was added with inorganic fertilizers. Increase in available potassium under STCR approach involving IPNS might be due to direct addition of available $\mathrm{K}$ to soil as well as reduction of potassium $m$ fixation and release of potassium due to interaction of organic matter with clay (Katkar et al., 2011).

\subsection{Water soluble potassium}

The lowest value in control where no inorganic fertilizers or manures were applied was statistically at par with farmers' practice (after wheat harvest, rabi, 2014-15). Application of general recommended dose significantly increased the water soluble K by 20.5 and $15.0 \%$ over control and farmers' practice, respectively. The STCR (IPNS) approach for target yield of 25 and $35 \mathrm{q} \mathrm{ha}^{-1}$ significantly increased the water soluble $K$ content by 7.8 and $10.6 \%$ over the same treatment without FYM.

However, after harvest of wheat (rabi, 2015-16), the highest value in $\mathrm{T}_{8}$ was at par with water soluble $\mathrm{K}$ in $\mathrm{T}_{7}$. The treatment under STCR approach for target yield of 25 and $35 \mathrm{q} \mathrm{ha}^{-1}$ without FYM increased the water soluble $\mathrm{K}$ content by 6.3 and $15.2 \%$ over general recommended dose.

The water soluble potassium increased significantly in treatments where inorganic fertilizers alone or in combination with FYM were applied over control. In farmers' practice, higher water soluble $\mathrm{K}$ content over control might be due to additional supply of $K$ from FYM. Addition of $K$ by potassium fertilizer and organic manures which contains significant amount of $\mathrm{K}$ released the water soluble $\mathrm{K}$ in soil. Similar findings were reported by Sawarkar et al. (2013), Habib et al. (2014) and Meena and Biswas (2014).

\subsection{Exchangeable potassium}

The lowest value of exchangeable $\mathrm{K}$ in control was statistically inferior in comparisons to all other treatments (Table 3 ). During 2014-15, the exchangeable $\mathrm{K}$ in farmers' practice was significantly enhanced by $18.2 \%$ over control. Similarly,

\begin{tabular}{lcccccc}
\hline Table 3: Effect of prescription based fertilizer application on soil potassium fractions $\left(\mathrm{mg} \mathrm{kg}^{-1}\right)$ \\
\hline
\end{tabular}

exchangeable $\mathrm{K}$ was significantly increased under the treatment involving general recommended dose and soil test based by 29.9 and $37.7 \%$ over control, respectively. The exchangeable $\mathrm{K}$ under the STCR (IPNS) approach for target yield of 25 and $35 \mathrm{q} \mathrm{ha}^{-1}$ was slightly increased by 0.9 and
1.8 per cent over the corresponding treatment without FYM. Similarly, after wheat harvest (2015-16), its value under the treatment general recommended dose and soil test based was significantly improved in soil by 30.7 and $38.7 \%$ over control, respectively. The treatment under STCR approach 
for target yield of 25 and $35 \mathrm{q} \mathrm{ha}^{-1}$ without FYM increased the exchangeable $\mathrm{K}$ content by 8.2 and $13.3 \%$ over general recommended dose. The exchangeable $\mathrm{K}$ under IPNS treatment for target yield 25 and $35 \mathrm{q} \mathrm{ha}^{-1}$ was at par with the same treatment without FYM.

In both the years, the content of exchangeable potassium was higher under treatments where inorganic fertilizers alone or in combination with FYM were applied over control which might be due to reduction in potassium fixation caused by repeated addition of manures along with potassic fertilizers (Sepehya, 2011). The additional supply of organic manures increased the CEC of the soil, which can hold more exchangeable potassium and convert potassium from non exchangeable form to exchangeable form, consequent to mass action effect (Black, 1968). These results were also reported by Sawarkar et al. (2013); Meena and Biswas (2014).

\subsection{Non exchangeable potassium}

Application of FYM along with inorganic fertilizers for target yield $35 \mathrm{q} \mathrm{ha}^{-1}$, which recorded highest non exchangeable $\mathrm{K}$ was at par with all treatments except $\mathrm{T}_{1}$ (control) and $\mathrm{T}_{2}$ (farmers' practice). Farmers' practice also recorded significant enhancement of $1.5 \%$ over control. The data further revealed that application of general recommended dose and soil test based increased the non exchangeable $\mathrm{K}$ over control by 8.8 and $9.1 \%$, respectively (Table 3 ). However, after wheat harvest (rabi, 2015-16), the lowest value in control was statistically at par with farmers' practice. All other treatments significantly increased non- exchangeable K over unfertilized plots. This might be attributed to the regular application of inorganic fertilizers which suggest that current dose of fertilizer application was sufficient to sustain $\mathrm{K}$ fertility. Applications of FYM under STCR approach reduces the amount of inorganic fertilizers and maintain soil fertility. These results were in conformity with those of Meena and Biswas (2014), Jatav et al. (2010) and Sharma et al. (2013).

\subsection{Relationship of different forms of potassium}

All the fractions of potassium were positively and significantly correlated with each other (Table 4). The step- wise regression analysis (Table 5) showed that exchangeable $\mathrm{K}$ was the most important variable contributing about 94 per cent in the total variation in available- $\mathrm{K}$.

Table 4: Correlation coefficients ( $r$ ) of different potassium fractions

\begin{tabular}{lccc}
\hline & $2014-15$ & & Non- ex K \\
\hline Ex- K & Ws-K & Ex- K & \\
Non- ex K & $0.790^{* *}$ & $0.901^{* *}$ & $0.823^{* *}$ \\
Available K & $0.765^{* *}$ & $0.938^{* *}$ & Non- ex K \\
$2015-16$ & $0.773^{* *}$ & & \\
& & Exc- K & \\
Ex- K & Ws-K & & $0.739^{* *}$ \\
Non- ex K & $0.814^{* *}$ & $0.746^{* *}$ & $0.943^{* *}$ \\
Available K & $0.840^{* *}$ & $0.771^{* *}$ & \\
\hline
\end{tabular}

${ }^{* *}$ Significant at $(p=0.01)$ level of significance; Ws- K: water soluble K; Ex- K: exchangeable K; Non- ex K: non- exchangeable K

Table 5: Multiple regression equations indicating relationship between available $\mathrm{K}$ and different fractions of potassium

\begin{tabular}{|c|c|}
\hline Regression Equation & $\mathrm{R}^{2}$ \\
\hline \multicolumn{2}{|l|}{ 2014-15 } \\
\hline Available $\mathrm{K}=71.70+0.936^{* *}$ Exch. $\mathrm{K}$ & $0.9377^{* *}$ \\
\hline \multicolumn{2}{|l|}{$2015-16$} \\
\hline Available $\mathrm{K}=46.14+0.943^{* *}$ Exch. $\mathrm{K}$ & $0.9430^{* *}$ \\
\hline
\end{tabular}

${ }^{* *}$ Significant at $(p=0.01)$ level of significance

\section{Conclusion}

STCR (IPNS) approach of fertilizer application recorded relatively higher available $\mathrm{K}$ and all fractions of $\mathrm{K}$. This indicated the maintenance of soil potassium due to soil test based fertilizer recommendation under IPNS. Non- exchangeable potassium status of soil was not influenced significantly with the use of chemical fertilizers alone or in combination with organics. All treatments were statistically at par among themselves except farmers' practice and control which show decline in its content. Exchangeable $\mathrm{K}$ was the important fraction of potassium contributing towards available $\mathrm{K}$.

\section{Acknowledgement}

The authors are grateful to the Indian Institute of Soil Science, Bhopal for providing financial assistance through AICRP on STCR during the course of investigation.

\section{References}

Black, C.A., 1965. Methods of Soil Analysis. Part II. American Society of Agronomy, Madison, Wisconsin, USA.

Black, C.A., 1968. Soil-plant relationships, John Wiley and Sons, 
Inc. New York, London, 403.

Dutta, J., Sharma, S.P., Sharma, S.K., Sharma, G.D., Sankhyan, N.K., 2015. Indexing soil quality under long-term maize-wheat cropping system in an acidic Alfisol. Communications in Soil Science and Plant Analysis 46, 1841-1862.

Gomez, K.A., Gomez, A.A., 1984. Statistical Procedure for Agricultural Research. John Wiley and Sons, New York.

Grewal, J.S., Kanwar, J.S., 1966. Forms of potassium in Punjab Soils. Journal of the Indian Society of Soil Science 14(1), 63-67.

Habib, F., Javid, S., Saleem, I., Ehsan, S., Ahmad, Z.A., 2014. Potassium dynamics in soil under long term regimes of organic and inorganic fertilizer application. Soil Environment 33(2), 110-115.

Jatav, M.K., Sud, K.C., Trehan, S.P., 2010. Effect of organic and inorganic sources of phosphorus and potassium on their different fractions under potato-radish cropping sequence in a brown hill soil. Journal of the Indian Society of Soil Science 58, 388-393.

Katkar, R.N., Sonune, B.A., Kadu, P.R., 2011. Long-term effect of fertilization on soil chemical and biological characteristics and productivity under sorghum (Sorghum bicolor)-wheat (Triticum aestivum) system in vertisol. Indian Journal of Agricultural Sciences 81(8), 734-739.

Meena, M.D., Biswas, D.R., 2014. Phosphorus and potassium transformations in soil amended with enriched compost and chemical fertilizers in a wheat-soybean cropping system. Communications in Soil Science and Plant Analysis 45, 624-652.

Merwin, H.D., Peech, M., 1950. Exchangeability of soil potassium in the sand, silt and clay fractions as influenced by the nature of the complementary exchangeable cations. Soil Science Society of America Proceedings 15, 125-128.

Ram, S., Singh, V., Sirari, P., 2016. Effects of 41 years of application of inorganic fertilizers and farm yard manure on crop yields, soil quality, and sustainable yield index under a rice-wheat cropping system on Mollisols of north India. Communications in Soil Science and Plant Analysis 47, 179-193.

Rao, Ch.S., 2014. Potassium recommendations in Indian agriculture: Emerging concepts. Journal of the Indian Society of Soil Science 62, 131-142.

Sanyal, S.K., 2014. Potassium- The neglected major plant nutrients in soil-crop management practices. Journal of the Indian Society of Soil Science 62, 117-130.

Sawarkar, S.D., Khamparia, N.K., Thakur, R., Dewda, M.S., Singh, M., 2013. Effect of long-term application of inorganic fertilizers and organic manure on yield, potassium uptake and profile distribution of potassium fractions in Vertisol under soybean-wheat cropping system. Journal of the Indian Society of Soil Science 61, 94-98.

Sepehya, S., 2011. Long-term effect of integrated nutrient management on dynamics of nitrogen, phosphorus and potassium in rice-wheat system. Ph.D. Thesis, Department of Soil Science, CSK Himachal Pradesh Krishi Vishvavidyalaya, India.

Sharma, S., Chander, G., Verma, T.S., Verma, S., 2013. Soil potassium fractions in rice-wheat cropping system after twelve years of lantana residue incorporation in a northwest Himalayan acid Alfisol. Journal of Plant Nutrition 36, 1809-1820.

Sutton, P., Seay, W.A., 1958. Relationship between the potassium removed by millet and red clover and the potassium extracted by 4 chemical methods from 6 Kentucky soils. Soil Science Society of America Proceedings 22, 110-115.

Tiwari, L.B., Mishra, D.D., Gupta, J., 2013. Evaluation of integrated nutrient management options in rice (Oryza sativa)- wheat (Triticum aestivum) cropping system in reclaimed sodic land. Indian Journal of Agronomy 58(2), 137-145.

Verma, S.D., 1979. Characteristics and genesis of soils of Himachal Pradesh. Ph.D. Thesis, Department of Soil Science, CSK Himachal Pradesh Krishi Vishvavidyalaya, Palampur, India. 